\title{
Genetic polymorphisms of leptin and leptin receptor genes in relation with production and reproduction traits in cattle*
}

\author{
Anna Trakovická ${ }^{凶}$ Nina Moravčíková and Radovan Kasarda \\ Department of Animal Genetics and Breeding Biology, Slovak University of Agriculture in Nitra, Nitra, The Slovak Republic
}

\begin{abstract}
Leptin and leptin receptor genes are considered as production traits markers in dairy or beef cattle. The aim of this study was to verify the associations of polymorphisms in bovine LEP and LEPR genes with production and reproduction traits in Slovak Spotted and Pinzgau cows. Long-life production was evaluated: milk, protein, and fat yield and reproduction traits: age at first calving, calving interval, days open, and insemination interval. In total, 296 blood samples of Slovak Spotted and 85 hair roots samples of Pinzgau cows were analyzed. In order to detect LEP/Sau3AI (BTA 4, inron 2) and LEPR/T945M (BTA 3, exon 20) genotypes PCR-RFLP method was used. In Slovak Spotted and Pinzgau cows allele frequencies were $0.838 / 0.162$ and $0.694 / 0.306$ for $A$ and $B$ LEP variants, and $0.954 / 0.046$ and $0.912 / 0.088$ for C and T LEPR variants, respectively. For testing the associations between SNPs LEP/Sau3AI and LEPR/T945M and evaluated traits, the General Linear Model procedure in SAS Software was used. Statistical analysis showed that SNP LEP/ Sau3AI significantly affected milk, protein and fat yield $(P<0.05)$, and age at first calving $(P<0.01)$ in analyzed population of cows. Statistically, SNP LEPR/T945M affected significantly calving interval $(P<0.01)$ only. Results of our study suggest that especially leptin is a candidate gene, which influences mainly milk production traits and might be implemented in breeding strategies to improve the production performance of both analyzed cattle breeds.
\end{abstract}

Key words: cattle; leptin; leptin receptor; milk production; polymorphism; reproduction

Received: 15 October, 2013; revised: 06 December, 2013; accepted: 10 December, 2013; available on-line: 29 December, 2013

\section{INTRODUCTION}

The importance of reproduction traits in dairy cattle breeding programs has dramatically increased recently. Achievement and profitability of modern cattle production determined stable and efficient reproduction. Milk yield in dairy cattle is governed both by genetic and environmental factors. Animals are subject to constant improvement for this quantitative trait, which is based on phenotype observations of cows and evaluation of the progeny and kins. Most associations between the polymorphism at a given locus and the phenotypic variability are virtually meaningless, or appear in local populations only. Thus, the research in pursuit of a functional marker, which would be of importance for selection, focuses mainly on protein-coding genes involved in the processes of lactation, as well as the genes that regulate these complex processes.
Leptin is a polypeptide hormone synthesized and secreted primarily in the adipose cells (Forhead \& Fowden, 2009). Leptin binds to a receptor mainly localized on Neuropeptid - Y - neurons, which in hypothalamus appear also to play a key role in the integration of feeding behaviour with internal signals of body energy status (Wayne et al., 1995). As leptin concentrations are strongly influenced by adipose tissue mass, leptin is thought to be a key signalling molecule linking nutritional status to reproductive function. An adequate amount of circulating leptin appears to be necessary for the attainment of puberty (Cunningham et al., 1999). Leptin may help regulate ovarian development and steroidogenesis, and serve as either a primary signal initiating puberty, or as a permissive regulator of sexual maturation (Lindersoon et al., 1998). In cattle, LEP gene is located on chromosome 4. It consists of tree exons and two introns of which only 2 exons are translated into protein. The coding region of LEP gene (501 nucleotide length) is contained in exon 2 and 3 (Liefers et al., 2002). SNP LEP/Sau3AI is situated in the second intron and results in amino acid change at position 2059 of the protein chain (cytosine, C to thymine, $\mathrm{T}$ ).

Effects of leptin are exerted trough six isoforms of leptin receptor. The leptin receptor is a glycoprotein with a single transmembrane-spanninng region. The long, fully active isoform (LEPR-b) is expressed mainly in hypothalamus, where it takes part in energy homeostasis and in regulation of the activity of the secretory organs, it may also act in many peripheral tissues, including gonadal tissues (Matteis et al., 2012). Leptin receptors are present in the ovary, where leptin can modulate steroidogenesis and improve the ability of the oocyte to sustain subsequent embryonic development (Boelhauve et al., 2005). LEPR gene is located on bovine chromosome 3. The leptin receptor gene consists of 20 exons divided over $1.75 \mathrm{Mb}$. Inside LEPR gene, Liefers et al. (2004) described a missense mutation T945M. It is a cytosine to thymine base substitution at position 115 in exon 20, which results in a substitution of the aimino acid (threonine, $\mathrm{T}$ to methionine, M) at residue 945 of leptin. SNP T945M may

e-mail: nina.moravcikova1@gmail.com

*Presented at the 5th Central European Congress of Life Sciences "EUROBIOTECH 2013", Kraków, Poland.

Abbreviations: BTA, bovine autosome; $\mathrm{H}_{\mathrm{e}}$, heterozygosity; $\mathrm{H}_{\mathrm{o}}$, homozygosity; $L E P$, leptin; $L E P R$, leptin receptor; $L E P / S a u 3 A l$, name of single nucleotide polymorphism in leptin gene; LEPR/T945M, name of single nucleotide polymorphism in leptin receptor gene; $\mathrm{N}_{\text {, ef- }}$ fective allele number; PIC, polymorphic information content; PCR, polymerase chain reaction; RFLP, restriction fragment length polymorphism; SNP, single nucleotide polymorphism; Sau3AI, BseGl, restriction enzymes; TBE, electrophoresis buffer 
Table 1. Sequence of the primers, size and region of the amplified fragments in PCR and observed genotypes with size. of the digestion patterns

\begin{tabular}{|c|c|c|c|c|c|}
\hline Gene & Primer sequences & $\begin{array}{l}\text { Size } \\
(b p)\end{array}$ & $\begin{array}{l}\text { Amplified } \\
\text { region }\end{array}$ & $\begin{array}{l}\text { Genotype/Digestion } \\
\text { patterns (bp) }\end{array}$ & Reference \\
\hline LEP & $\begin{array}{l}\text { F 5' -TGG AGT GGC TTG TTA TIT TCT TCT- 3' } \\
\text { R 5'-GTC CCC GCT TCT GGC TAC CTA ACT- } 3^{\prime}\end{array}$ & 422 & intron 2 & $\begin{array}{l}\text { AA } 390,32 \\
\text { AB 390, 303, 88, } 32 \\
\text { BB } 303,88,32\end{array}$ & Liefers et al. (2002) \\
\hline LEPR & $\begin{array}{l}\text { F 5'-ACTACAGATGCTCTACTITGG-3' } \\
\text { R 5'-TGCTCCTCCTCAGTIT-3' }\end{array}$ & 197 & exon 20 & $\begin{array}{l}\text { CC 130, } 67 \\
\text { CT } 130,93,67,37 \\
\text { TT } 93,67,37\end{array}$ & Almeida et al. (2008) \\
\hline
\end{tabular}

have induced a structural change in the intracellular domain of LEPR.

The aim of this study was to establish LEP and LEPR genes allele and genotypes frequencies, and significance of associations between these polymorphisms and long-life milk production, and reproduction traits in Slovak Spotted and Pinzgau cows.

\section{MATERIAL AND METHODS}

Animals and DNA extraction method. The study covered a total of 296 Slovak spotted and 85 Pinzgau cows. Evaluated cattle breeds belong to the dual purpose production type. Genomic DNA for animal's genotyping was extracted from blood samples and hair roots. DNA concentrations were calculated by spectrophotometer by taking the optical density at wave length of $260 \mathrm{~nm}$.

Analyses of polymorphisms. The analyzed polymorphic sites are situated within the second intron in the bovine LEP gene $(\mathrm{C} / \mathrm{T}$ transition results in amino acid change arginine by cysteine at position 2059 in the secreted protein) and the exon 20 in the bovine LEPR gene $(C / T$ transition at a position 115 , which results in a substitution of the aimino acid threonine by methionine at residue 945 of leptin). A 422 bp fragment of LEP gene was amplified by PCR using forward and reverse primers according to Liefers et al. (2002). The polymerase chain reaction was performed in a $25 \mu \mathrm{l}$ reaction mixtures, containing: $1 \times$ PCR buffer $\left(\mathrm{NH}_{4}\right)_{2} \mathrm{SO}_{4}$, $1.5 \mathrm{mM} \mathrm{MgCl}$, $2 \mathrm{mM}$ dNTPs, $8 \mathrm{pM}$ primers, $1 \mathrm{U}$ Tag DNA polymerase and $50 \mathrm{ng}$ genomic DNA. Thermal cycling conditions included: an initial denaturation step at $95^{\circ} \mathrm{C} / 5 \mathrm{~min}$, followed by 30 cycles of $95^{\circ} \mathrm{C} / 30$ sec, $55^{\circ} \mathrm{C} / 20 \mathrm{sec}, 72^{\circ} \mathrm{C} / 30 \mathrm{sec}$ and a final extension at $72^{\circ} \mathrm{C} / 7 \mathrm{~min}$. Amplification of a $197 \mathrm{bp}$ fragment of LEPR gene was performed with appropriate primer pairs proposed by Almeida et al. (2008). DNA was amplified in a total volume of $25 \mu \mathrm{l}$ containing: $1 \times$ PCR buffer $\left(\mathrm{NH}_{4}\right)_{2} \mathrm{SO}_{4}, 2 \mathrm{mM} \mathrm{MgCl} 2,2 \mathrm{mM}$ dNTPs, $6 \mathrm{pM}$ primers, $1 \mathrm{U}$ Tag DNA polymerase and $50 \mathrm{ng}$ genomic DNA. PCR conditions were at $94^{\circ} \mathrm{C} / 3 \mathrm{~min}$, followed by 35 cycles of $94^{\circ} \mathrm{C} / 30 \mathrm{~s}, 51^{\circ} \mathrm{C} / 50 \mathrm{~s}$ and $72^{\circ} \mathrm{C} / 30 \mathrm{~s}$. After 35 cycles, reactions were completed by an extension at $72^{\circ} \mathrm{C} / 5 \mathrm{~min}$. PCR products of LEP and LEPR genes were digested at $37^{\circ} \mathrm{C}$ in time $10 \mathrm{~min}$ with $1 \mu \mathrm{l}$ of FastDigest restriction enzymes SauBAI and BseGI, respectively. The digestion products were separated by horizontal electrophoresis in 3\% agarose gels in $0.5 \times$ TBE $(130 \mathrm{~V}$ for $50 \mathrm{~min}$ ) stained with GelRed prior to visualization under UV light.

Statistical analysis. The allele and genotype frequencies of LEP and LEPR genes were estimated by direct counting, and the differences of the observed and expected frequencies of genotypes were tested using Chisquare $\left(\chi^{2}\right)$ test in order to verify if the population was in
Hardy-Weinberg equilibrium. Genetic indices of population, including observed and expected genes heterozygosity $\left(H_{\mathrm{e}}\right)$, homozygosity $\left(H_{\mathrm{o}}\right)$ and effective allele numbers $(N)$ were performed by Popgene32 software version 1.3 (Yeh et al., 2000). Moreover, polymorphism information content (PIC) was calculated according to Botstein et al. (1980). Associations of the animal genotypes with long-life milk production and reproduction traits were determined by analyses of quantitative traits. Statistical analysis was performed using SAS Enterprise Guide 4.2 software (SAS Institute Inc., 2009), and significance of differences based on genotypes effect of production and reproduction traits were tested by following general linear models:

$$
\begin{aligned}
& \mathrm{Y}_{\mathrm{i} k \mathrm{k} l m n}{ }^{1,2,3}=\mathrm{G}_{\mathrm{i}}+\mathrm{BT}_{\mathrm{j}}+\mathrm{S}_{\mathrm{k}}+\mathrm{A}_{1}+\mathrm{CI}_{\mathrm{m}}+\mathrm{L}_{\mathrm{n}}+\mathrm{e}_{\mathrm{i} \mathrm{j} \mathrm{klmn}} \\
& \mathrm{Y}_{\mathrm{ijk}}{ }^{4}=\mathrm{G}_{\mathrm{i}}+B \mathrm{BT}_{\mathrm{j}}+\mathrm{S}_{\mathrm{k}}+\mathrm{e}_{\mathrm{ijk}} \\
& \mathrm{Y}_{\mathrm{ijklmn}}{ }^{5}=\mathrm{G}_{\mathrm{i}}+\mathrm{BT}_{\mathrm{j}}+\mathrm{S}_{\mathrm{k}}+\mathrm{DO}_{1}+\mathrm{MY}_{\mathrm{m}}+\mathrm{L}_{\mathrm{n}}+\mathrm{e}_{\mathrm{ijklmn}} \\
& \mathrm{Y}_{\mathrm{ijklm}}{ }^{6}=\mathrm{G}_{\mathrm{i}}+\mathrm{BT}_{\mathrm{j}}+\mathrm{S}_{\mathrm{k}}+\mathrm{MY}_{1}+\mathrm{I}_{\mathrm{m}}+\mathrm{e}_{\mathrm{ijklm}} \\
& \mathrm{Y}_{\mathrm{ijklm}}{ }^{7}=\mathrm{G}_{\mathrm{i}}+\mathrm{BT}_{\mathrm{j}}+\mathrm{S}_{\mathrm{k}}+\mathrm{MY}_{1}+\mathrm{L}_{\mathrm{m}}+\mathrm{e}_{\mathrm{ijklm}}
\end{aligned}
$$

where: $Y_{\mathrm{i}: \mathrm{klmn}} 1,2,3-$ milk, protein and fat yield, $Y_{\mathrm{ijk}}{ }^{4}-$ age at first calving, $Y_{\mathrm{ijk} k m n}{ }^{5}$ - calving interval, $\mathrm{Y}_{\mathrm{i} \mathrm{klm}}{ }^{6}$ - days open, $\mathrm{Y}_{\mathrm{i} \mathrm{ikm}}{ }^{7}$ - insemination interval, $G_{\mathrm{i}}$ - effect of genotype, $B T_{j}$ - effect of breed type, $S_{k}$ - effect of sire, $A_{1}$ - effect of age at first calving, $\mathrm{DO}_{1}$ - effect of days open, $\mathrm{CI}_{\mathrm{m}}$ - effect of calving interval, $L_{n}, L_{m}$ - effect of number of lactation, $\mathrm{MY}_{\mathrm{m}}, \mathrm{MY}_{1}$ - effect of milk yield, $\mathrm{I}_{\mathrm{m}}$ - effect of insemination interval, $e_{i j k}, e_{i j k l m}, e_{i j k l m n}-$ random error.

\section{RESULTS}

Three genotypes for $L E P / \operatorname{Sau} 3 A I(\mathrm{AA}, \mathrm{AB}$, and $\mathrm{BB})$ were identified. For LEPR gene only two genotypes (CC and CT) were detected, whereas T'T genotype was not observed. Frequencies of individual alleles and genotypes in the analyzed populations of Slovak Spotted and Pinzgau cows are presented in Table 2. The highest frequencies of SNP LEP/Sau3AI were observed for homozygous AA genotype in Slovak Spotted cows and heterozygous $\mathrm{AB}$ genotypes in Pinzgau cows, and lowest for homozygous $\mathrm{BB}$ genotype in both analyzed populations. For SNP LEPR/T945M was predominant in both cows populations CC homozygous genotype. Slovak Spotted and Pinzgau cows populations were in Hardy-Weinberg equilibrium ( $p>0.05)$. The heterozygosity, effective allele numbers and polymorphism information content of SNPs LEP/Sau $3 A$ and LEPR/T945M in two analyzed populations are presented in Table 2. The decrease in heterozygosity can be caused as result of eventual populations inbreeding. The low heterozygosity values indicate, that inbreeding probably may be a potential prob- 
Table 2. Distribution of SNPs LEP/Sau3AI and LEPR/T945M alleles and genotypes in Slovak Spotted and Pinzgau cows.

\begin{tabular}{|c|c|c|c|c|c|c|c|c|c|}
\hline \multirow{2}{*}{ Breed } & \multicolumn{3}{|c|}{ Genotype frequency } & \multicolumn{2}{|c|}{ Allele frequency } & \multirow{2}{*}{$\begin{array}{l}X^{2} \\
\text { test }\end{array}$} & \multirow{2}{*}{$H_{\mathrm{e}}$} & \multirow{2}{*}{ PIC } & \multirow{2}{*}{$\mathrm{N}_{\mathrm{e}}$} \\
\hline & LEP/Sau3AIAA & LEP/Sau3AlAB & LEP/Sau3AIBB & LEP/Sau3AIA & LEP/Sau3AlB & & & & \\
\hline SS & 0.70 & 0.27 & 0.03 & 0.839 & 0.161 & $0.18^{-}$ & 0.28 & 0.25 & 1.39 \\
\hline \multirow[t]{2}{*}{$P$} & 0.45 & 0.49 & 0.06 & 0.694 & 0.306 & $2.23^{-}$ & 0.42 & 0.34 & 1.74 \\
\hline & LEPR/T945McC & LEPR/T945Mct & LEPR/T945M"T & LEPR/T945Mc & LEPR/T945M ${ }^{\top}$ & & & & \\
\hline SS & 0.92 & 0.08 & - & 0.958 & 0.043 & $0.20^{-}$ & 0.08 & 0.08 & 1.09 \\
\hline P & 0.82 & 0.18 & - & 0.911 & 0.088 & 1.26 & 0.16 & 0.15 & 1.19 \\
\hline
\end{tabular}

$P>0.05$, SS - Slovak spotted, $\mathrm{P}$ - Pinzgau, $\mathrm{H}_{\mathrm{e}}$ - observed heterozygosity, $\mathrm{H}_{\mathrm{o}}$ - observed homozygosity, PIC — polymorphic information content, $\mathrm{N}_{\mathrm{e}}$ - effective allele number

Table 3. Basic statistical variation measurements of long-life milk production and reproduction traits

\begin{tabular}{|c|c|c|c|c|c|c|c|c|c|}
\hline \multicolumn{10}{|c|}{ Milk production traits } \\
\hline & \multicolumn{3}{|c|}{ Slovak Spotted cows } & \multicolumn{3}{|c|}{ Pinzgau cows } & \multicolumn{3}{|c|}{ Total } \\
\hline & $\mathrm{n}$ & mean & SD & $\mathrm{n}$ & mean & SD & $\mathrm{n}$ & mean & SD \\
\hline MY (kg) & 248 & 20668.45 & 8310.80 & 83 & 17316.98 & 11300.86 & 331 & 19828.05 & 9249.22 \\
\hline PY (kg) & 248 & 703.05 & 274.12 & 83 & 659.31 & 421.22 & 331 & 678.55 & 306.79 \\
\hline $\mathrm{FY}(\mathrm{kg})$ & 248 & 829.87 & 336.59 & 83 & 605.35 & 381.06 & 331 & 787.09 & 366.56 \\
\hline \multicolumn{10}{|c|}{ Reproduction traits } \\
\hline $\mathrm{AFC}(\mathrm{d})$ & 248 & 896.23 & 117.98 & 83 & 1054.70 & 122.61 & 331 & 936.01 & 137.42 \\
\hline $\mathrm{Cl}(\mathrm{d})$ & 240 & 404.04 & 64.62 & 66 & 386.18 & 56.93 & 306 & 404.58 & 70.58 \\
\hline $\mathrm{DO}(\mathrm{d})$ & 224 & 117.64 & 64.25 & 75 & 166.64 & 137.09 & 299 & 129.93 & 90.60 \\
\hline II & 224 & 73.72 & 31.52 & 75 & 88.44 & 79.64 & 299 & 77.41 & 48.58 \\
\hline
\end{tabular}

$\mathrm{n}$ - number of individuals, mean - average value, S.D. — standard deviation, MY - milk yield, PY — protein yield, FY — fat yield, AFC — age at first calving, $\mathrm{Cl}$ - calving interval, DO - days open, II - insemination interval

lem at the population level, therefore should be included pedigree information in further population's evaluation. According to the classification of PIC (low polymorphism if PIC value $<0.25$, median polymorphism if $0.25<\mathrm{PIC}$ value $<0.5$, and high polymorphism if PIC value $>0.5)$ (Botstein et al., 1980), the analyses show low (LEPR/T945M) or median (LEP/Sau3AI) levels of polymorphic information content of analyzed SNPs across populations based on the expected heterozygosity. The effectiveness of loci allele impact in populations has been expressed by effective allele numbers. Providing that in biallelic system both alleles result in the genotypes creation, threshold value is 2,000. Comparison of $\mathrm{N}_{\mathrm{e}}$ showed higher effective allele numbers across populations for SNP LEP/Sau3AI and indicated good level of genetic variability in analyzed cows population at the considered locus.

Table 3 and 4 shows average values of analyzed production and reproduction traits in relation to specific genotype in analyzed cows populations. Significance of observed differences in association analyses between polymorphisms and analyzed traits was affected by number of data available for particular trait. Only animals with relevant data of production and reproduction parameters were used in subsequent analyses.

The study results of SNP LEP/Sau3AI show significant differences between the long-life milk production traits $(P<0.05)$ and age at first calving $(P<0.01)$. Cows of homozygous $L E P / S a u 3 A I^{A A}$ genotype were characterized by highest milk, protein and fat yield and lowest age at first calving. The opposite relationships between milk production and $L E P / \operatorname{Sau} 3 A I$ genotypes were found in the group of cows of $L E P / \operatorname{Sau} 3 A I^{B B}$ genotype. The highest age at first calving was determined in heterozy- gous LEP/Sau3AIAB cows. Differences between other analyzed traits were very low and non-significant.

The statistical analysis of LEPR genotype effect on long-life milk production and reproduction traits shows significant differences $(P<0.01)$ only for length of calving interval. The shorter calving interval was characterized for group of cows with heterozygous LEPR/ T945M ${ }^{\text {CT }}$ genotype. This genotype was also favourable for days open and insemination interval, but only nonsignificant. Significant results of association analyses between LEPR/T945M genotypes and analyzed production and reproduction traits were affected by number of identified heterozygous individuals and missing homozygous TT genotype.

\section{DISCUSSION}

Improvement of production traits and increase of genetic and economic gain are the aim of all cattle breeders. This gain can be achieved with traditional selection programs or breeding programs using genetic markers. Marker assisted selection or genomic selection in livestock uses quantitative trait loci and candidate genes, which directly or indirectly affect phenotype of individuals. Analyses of increase genetic gain using marker assisted selection can put genetic evaluation more exactly and decrease time, which is needed for realization in cattle breeding. It is generally accepted that leptin plays a key role during pregnancy, in feed intake, energy expenditure and growth, or reproduction functions of dairy cattle, and leptin gene might be a strong candidate for economically important production traits. For leptin hormone functioning leptin receptor is necessary. This receptor is 


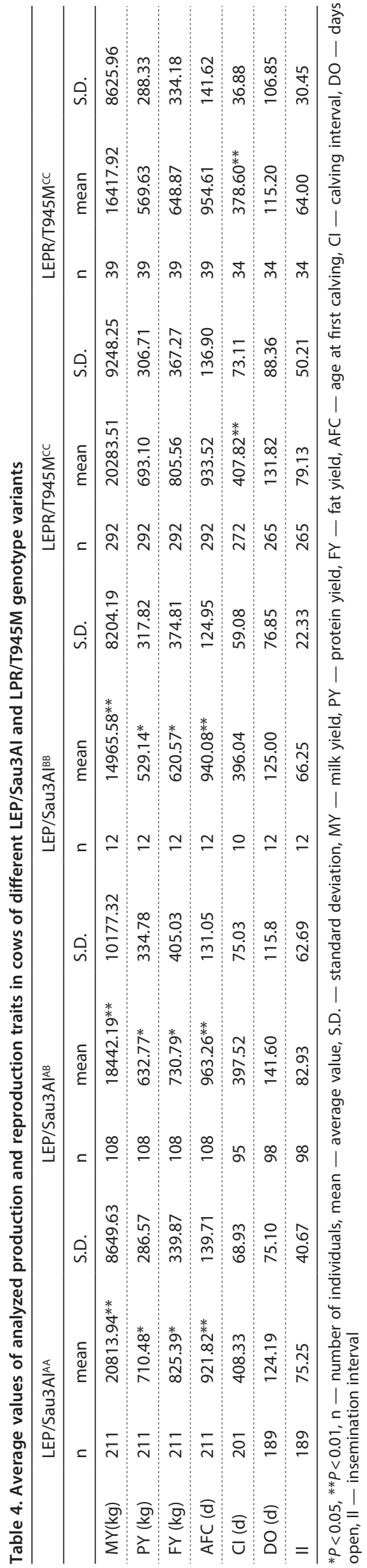

involved also in regulation of secretory organs activity. Among potential genetic markers analyzed in this study, $L E P / S a u 3 A I^{A}$ allele can play a role in determination of level of milk, protein and fat yield, and age at first calving and LEPR/T945MC allele in determination of length of calving interval. The Effect of leptin and leptin receptor genes were evaluated in many studies on different cattle breeds. The SNP LEP/Sau3AI have been significantly associated with somatic cells count (Kulig et al., 2010), milk production traits (Anton et al., 2012; Liefers et al., 2002), reproduction traits (Chebel \& Santos, 2011; Almeida et al., 2003) and growth traits (Kulig \& Kmieć, 2009; Othamn et al., 2011). For SNP LEPR/T945M effect on milk production traits (Glantz et al., 2012), reproduction traits (Clempson et al., 2011; Glantz et al., 2011; Komisarek, 2010) and growth traits (Almeida et al., 2008; Silva et al., 2012) was confirmed. Selection of animals with LEP/Sau3AI or LEPR/T945M genotype could have beneficial results in production and reproduction traits in cows.

In conclusion, genes encoding hormones, growth factors, and other regulatory proteins associated with milk production and reproduction can be evaluated as a genetic markers candidate for quantitative traits in farm animals. We confirmed that $L E P /$ Sau $3 A I$ genotypes may cause differences in milk production phenotypes, and also SNP affected the reproduction of analyzed individuals. Statistical analyses of associations between LEPR/ T945M genotypes and analyzed traits were significant only for length of calving interval. The leptin and leptin receptor genes could contribute to the progress in selection of farm animals, whereas for application in breeding practice confirmation of their effect is needed by further associations analyses. The confirmation of our results can increase economic effectiveness of animal production resulting from selection of individuals with preferred genotype.

\section{Acknowledgements}

This work was supported by the project: Development of International Cooperation for the Purpose of the Transfer and Implementation of Research and Development in Educational Programs conducted by the Operational Program: Education, ITMS code: 26110230085 and by the Slovak Research and Development Agency under the contract No. APVV-0636-11 and LPP-022009.

\section{REFERENCES}

Almeida SEM, Almeida EA, Moraes JCF, Weimer TA (2003) Molecular markers in the LEP gene and reproductive performance of beef cattle. I Anim Breed Genet 12: 106-113.

Almeida SEM, Santos LBS, Passos DT, Corbellini AO, Lopes BMT, Kirst C, Terra G, Neves JP, Goncalves PBD, Moraes JCF, Azevedo Weimer T (2008) Genetic polymorphsims at the leptin receptor gene in three beef cattle breeds. Genet Mol Biol 31: 680-685.

Anton I, Kovács K, Holló G, Farkas V, Szabó F, Egerszegi I, Rátky J, Zsolnai A, Brüssow KP (2012) Effect of DGAT1, leptin and TG gene polymorphisms on some milk production traits in different dairy cattle breeds in Hungary. Arch Tierz 55: 307-414.

Boelhauve M, Sinowatz F, Wolf E, Paula-Lopes FF (2005) Maturation of bovine oocytes in the presence of leptin improves development and reduces apoptosis of in vitro-produced blastocysts. Biol Reprod 73: $737-744$.

Botstein D, White RL, Skolnik M, Davis RW (1980) Construction of a genetic linkage map in man using restriction fragment length polymorphism. Amer I Hum Genet 32: 314-331.

Chebel RC, Santos JEP (2011) Association between leptin single nucleotide polymorphism and reproductive performance of lactating Holstein cows. Anim Reprod Sci 127: 126-134. 
Clempson AM, Pollott GE, Brickell JS, Bourne NE, Munce N, Wathes DC (2011) Evidence that leptin genotype is associated with fertility, growth, and milk production in holstein cows. J Dairy Sci 94: 3618-3628.

Cunningham MJ, Clifton DK, Steiner RA (1999) Leptins actions on the reproductive axis: perspectives and mechanisms. Biol Reprod 60: 216-222.

Forhead AJ, Fowden AL (2009) The hungry fetus? Role of leptin as a nutritional signal before birth. J Physiol 587: 1145-1152.

Glantz M, Lindmark Månsson H, Stålhammar H, Paulsson M (2012) Effect of polymorphisms in leptin, leptin receptor and acyl-CoA: diacylglycerol acyltransferase 1 (DGAT1) genes and genetic polymorphism of milk proteins on bovine milk composition. J Dairy Res 79: $110-118$.

Glantz M, Lindmark Månsson H, Stålhammar H, Paulsson M (2012) Effect of polymorphisms in leptin, leptin receptor and acyl-CoA: diacylglycerol acyltransferase 1 (DGAT1) genes and genetic polymorphism of milk proteins on bovine milk composition. J Dairy Res 79: 110-118.

Komisarek J (2010) Imapct of LEP and LEPR gene polymorphisms on functional traits in Polish Holstein-Friesian cattle. Anim Sci Pap Rep 28: 133-141.

Kulig H, Kmieć M (2009) Association between leptin Gene Polymorphisms and growth Traits in Limousin Cattle. Russian J Genetics 45: 738-741.

Kulig H, Kmieć M, Wojdak-Maksymiec K (2010) Associations between Leptin Gene Polymorphisms and Somatic Cell Count in Milk of Jersey Cows. Acta Vet Brno 79: 237-242.

Liefers SC, Pas MFW, Veerkamp RF, Van der Lende T (2002) Associations between leptin gene polymorphisms and production, live weight, energy balance, feed intake, and fertility in Holstein heifers. J Dairy Sci 85: 227-238.
Liefers SC, Veerkamp RW, Te Pas MFW, Delavaud C, Chilliard Y, Van der Lende T (2004) A missense mutation in the bovine leptin receptor gene is associated with leptin concentrations during late pregnancy. Anim Genet 35: 138-141.

Lindersoon M, Andersson-Eklund L, Koning DJ, Lunden A, Maki-Tanila A, Andersson L (1998) Mapping of serum amylase-1 and quantitative trait loci for milk production traits to cattle chromosome 4 . J Dairy Sci 81: 1454-1461.

Matteis G, Scatà MC, Grandoni F, Petrera F, Abeni F, Catillo G, Napolitano F, Moioli B (2012) Association analyses of single nucleotide polymorphisms in the leptin and leptin receptor genes on milk and morphological traits in Holstein cows. Open J Animal Science 2: $174-182$.

Othman OE, Zayed FA, El Gawead AA (2011) Genetic polymorphism of two genes associated with carcass trait in Egyptian buffaloes. Genet Eng Biotechnol J 9: 15-20.

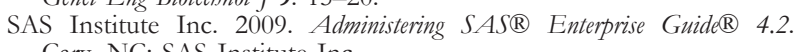
Cary, NC: SAS Institute Inc.

Silva RC, Ferraz JB, Meirelles FV, Eler JP, Balieiro JC, Cucco DC, Mattos EC, Rezende FM, Silva SL (2012) Associations of single nucleotide polymorphisms in the bovine leptin gene and leptin receptor genes with growth and ultrasound carcass traits in Nellore cattle. Genet Mol Res 17: (AOP).

Wayne J, Kuenzel WJ, Fraley GS (1995) Neuropeptid Y: It's in the Neural Regulation of Reproductive Function and Feed Intake in Mammalian Species. Poultry Avian Biol Rev 6: 185-209.

Yeh FC, Yang R, Boyle TJ, Ye Z, Xiyan JM (2000) PopGene32, Microsoft Windows-based freeware for population genetic analysis, version 1.32. Mol. Biol. Biotechnol. Centre, Univ. Alberta, Edmonton, Alberta, Canada. 